\title{
Intensive Care Admissions and Outcomes Associated with Short- Term Exposure to Ambient Air Pollution: A Time Series Analysis
}

Christopher P. Groves (Department of Intensive Care, Royal North Shore Hospital, Sydney, NSW, Australia), Barbara K. Butland (Population Health Research Institute, St George's, University of London, UK), Richard W. Atkinson (Population Health Research Institute, St George's, University of London, UK), Anthony P. Delaney (Department of Intensive Care, Royal North Shore Hospital, NSW, Sydney, Australia), David V. Pilcher (Department of Intensive Care, Alfred Hospital, Melbourne, VIC, Australia. Australia and New Zealand Intensive Care Society (ANZICS) Centre for Outcomes and Resource Evaluation (CORE), Carlton, VIC, Australia).

\section{Authorship}

All authors contributed to study conception and design. Data collection and preparation was performed by CPG. Analysis was performed by BKB. The manuscript was written by CPG and all authors commented on previous versions of the manuscript. All authors read and approved the final manuscript.

\section{Conflict of Interest Statement}

Ms Butland owns shares in Royal Dutch Shell and Scottish and Southern Energy and her spouse has a deferred Shell pension. All other authors declare no conflicts of interest.

\section{Abstract}

\section{Purpose}

Short-term exposure to outdoor air pollution has been positively associated with numerous measures of acute morbidity and mortality, most consistently as excess cardiorespiratory disease associated with fine particulate matter $\left(\mathrm{PM}_{2.5}\right)$, particularly in vulnerable populations. It is unknown if the critically ill; a vulnerable population with high levels of cardiorespiratory disease, is affected by air pollution.

\section{Methods}

We performed a time series analysis of emergency cardiorespiratory, stroke and sepsis intensive care (ICU) admissions for the years 2008 - 2016, using data from the Australian and New Zealand Intensive Care Society Adult Patient Database (ANZICS-APD). Case-crossover analysis was conducted to assess the relationship between air pollution and the frequency and severity of ICU admissions having adjusted for temperature, humidity, public holidays and influenza activity.

$\underline{\text { Results }}$

46,965 episodes in 87 separate ICUs were analysed. We found no statistically significant associations with admission counts. However, ICU admissions ending in death within 30 days were significantly positively associated with short-term exposure to $\mathrm{PM}_{2.5}$ (RR 1.18, 95\% confidence interval (CI) 1.02 - 
1.37, per $10 \mu \mathrm{g} / \mathrm{m}^{3}$ increase). This association was more pronounced in those aged 65 and over (RR $1.33,95 \% \mathrm{Cl} 1.11-1.58$, per $10 \mu \mathrm{g} / \mathrm{m}^{3}$ ).

\section{$\underline{\text { Conclusions }}$}

Increased ICU mortality was associated with higher levels of $\mathrm{PM}_{2.5}$. Larger studies are required to determine if the frequency of ICU admissions is positively associated with short-term exposure to air pollution.

\section{$\underline{\text { Take Home Message }}$}

In a large time series study of emergency ICU admissions for cardiorespiratory disease, sepsis and stroke, fine particulate matter air pollution $\left(\mathrm{PM}_{2.5}\right)$ concentrations were significantly associated with an increased risk of ICU admission that ends in early death in ICU (within 30 days). This adds to existing observational evidence that $\mathrm{PM}_{2.5}$ is harmful to health and may lead to increased mortality in intensive care.

\section{$\underline{\text { Introduction }}$}

Outdoor air pollution is a leading cause of death and disability worldwide, estimated to contribute to 9 million premature deaths annually (16\% of total deaths) [1], with both short- and long-term exposure thought harmful [2]. Air pollution is a heterogeneous mixture of gaseous, liquid and solid compounds, varying with locale and emission source. Conventional markers of air pollution: particulate matter $(\mathrm{PM})$, nitrogen dioxide $\left(\mathrm{NO}_{2}\right)$, ozone $\left(\mathrm{O}_{3}\right)$ and sulphur dioxide $\left(\mathrm{SO}_{2}\right)$ are individually associated with harm [3-6]. However, they are never found in isolation and the true effect is likely exerted by these and many other unmeasured species.

PM has emerged as the constituent most significantly and consistently associated with harm [7]. PM is subcategorised as $\mathrm{PM}_{2.5}$, the mass concentration of particles with a diameter less than $2.5 \mu \mathrm{m}$ ('fine' PM), and $\mathrm{PM}_{10}$ if less than $10 \mu \mathrm{m} . \mathrm{PM}_{2.5}$ is particularly associated with risks to health, observed 1 and 3 days following exposure [8,9]. Smaller diameter is thought to confer deeper passage into the respiratory tree and circulatory translocation $[10,11]$. $\mathrm{NO}_{2}$ is usually representative of motor vehicle traffic and is associated with adverse outcomes in long- and short-term exposure studies [12].

In short-term pollution studies, increases in emergency hospital admissions and mortality have been found. These are mediated by excess cardiovascular, stroke and respiratory disease [9,13-15], particularly in susceptible populations such as the elderly $[16,17]$. Acute events increase within hours [18], with oxidative stress, pulmonary and systemic inflammation thought to result in vascular endothelial dysfunction, procoagulant states and autonomic dysfunction $[19,20]$; findings common in critical illness. Furthermore, patients admitted to the intensive care unit (ICU) are often elderly, have cardio-respiratory dysfunction and have a high risk of death and disability, suggesting they may be vulnerable to air pollution. There is little research on the effect of pollution on the ICU population, although $\mathrm{PM}$ and $\mathrm{NO}_{2}$ have been associated with longer mechanical ventilation [21], ozone and $\mathrm{PM}_{2.5}$ with an increase in acute respiratory distress syndrome $[22,23]$, and $\mathrm{PM}_{2.5}$ with pneumonia-related ICU admissions [24]. It is unknown whether patients admitted to ICU when air pollution is increased have worse outcomes. 
Sepsis-related hospital admissions were recently associated with $\mathrm{PM}_{2.5}$ [25] and the syndrome is characterised by dysregulated inflammatory response to infection, sharing many features with air pollution exposure. In view of this and robust associations between pollution, cardiorespiratory disease and stroke, we hypothesised that ICU admissions for these diseases are increased, and adverse outcomes more common, with increased air pollution. We conducted a time series analysis of short-term exposure to three pollutants $\left(\mathrm{PM}_{2.5}, \mathrm{PM}_{10}, \mathrm{NO}_{2}\right)$ and emergency ICU admissions in two Australian states: New South Wales (NSW) and Victoria.

\section{Methods}

\section{Study population}

The Australia and New Zealand Intensive Care Society (ANZICS) Adult Patient Database (APD) [26] is one of the world's largest ICU registries, with over 2 million episodes. Demographic, clinical and outcome data are submitted from over $90 \%$ of ICUs in these countries.

Access to the APD data was granted according to standing protocol published by the ANZICS Centre for Outcomes and Resource Evaluation (CORE) committee [27]. The study was approved by the Northern Sydney Local Health District Human Research Ethics Committee (LNR/17/HAWKE/430).

The study population and outcomes were defined a priori. Episode data were obtained on all unplanned, non-surgical ICU episodes in NSW and Victoria with an admission diagnosis of cardiorespiratory disease, stroke or sepsis (using ANZICS modification of the Acute Physiology and Chronic Health Evaluation (APACHE) III diagnostic codes) (S1) with initial hospital admission between $1^{\text {st }}$ January 2008 and $31^{\text {st }}$ December 2016 and ICU admission occurring within 24 hours of hospital admission. We excluded patients under 18 years, pregnancy, and those with a residential postcode over 10 kilometres $(\mathrm{km})$ from a pollution monitoring station. We included inter-hospital transfers but not transfers between ICUs to avoid double counting patients submitted to the APD twice during the same admission.

\section{Pollution Data}

Pollution data were obtained from the Environment Protection Authority of Victoria [28] and the Office of Environment and Heritage of NSW [29] (measurement techniques described in supplementary material). These are accredited by the National Association of Testing Authorities and conform to Australian and International standards. Stations are located away from large roads and industrial areas, and hence represent background pollutant levels.

\section{Covariate Data}

Covariates known to influence acute hospital and ICU admissions were considered. These were: temperature, humidity, influenza and public holidays. Meteorological data were obtained from the Australian Bureau of Meteorology and state-wide emergency department attendances for influenzalike illness from the Australian Centre for Epidemiology and Evidence. Public holidays were obtained from public records [30].

$\underline{\text { Statistical analysis }}$ 
Initial data manipulation was performed using R version 3.3.3 [31]. We used residential postcode centroids to geographically match ICU episodes with pollution data. For each pollutant, data were obtained from the single monitor within a $10 \mathrm{~km}$ radius of the postcode that provided the most complete time series of daily mean pollutant concentrations. Where two monitors provided the same amount of data, the nearest was chosen. We calculated the mean daily temperature and mean daily humidity for each postcode centroid over the study period based on all available measurements from monitoring stations within a $40 \mathrm{~km}$ radius.

Exposure - outcome relationships were assessed with case-crossover analysis [32]. This has become the standard for analysing acute events and short-term pollutant exposure (considered as a continuous variable). In this method, subjects serve as their own controls, reducing the effect of stable individual covariates.

Strata (one for each ICU episode) were formed by matching the day of hospital admission (case day) with up to 4 control days, where matching was by postcode, day of the week, month and year. The data were then analysed using conditional logistic regression in STATA [33]. Models were run for each pollutant separately with the pollution data included as 3 separate variables on the admission day, on the day prior and two days prior (lag 0 , lag 1 and lag 2). By combining the coefficients for the 3 exposure days we obtained a summary relative risk and $95 \%$ confidence interval estimating the effect on ICU admission of a 10-unit (10ppb for $\mathrm{NO}_{2}$ and $10 \mu \mathrm{g} / \mathrm{m}^{3}$ for particulates) increase in shortterm exposure. This representation of the pollutant is referred to as an unconstrained distributed lag model, lags 0-2 (UDLM 0-2). Analyses were conducted both with and without covariate adjustment. In the latter we adjusted for temperature and humidity lags 0-2 and 3-6 days (modelled as four natural cubic splines with 3 knots) (S2), influenza-like illness and public holidays.

We investigated the associations between short-term pollutant exposure and ICU admission by APACHE diagnosis categories; cardiovascular, respiratory, stroke and sepsis. We then excluded patients admitted to ICU for palliative care or organ donation and investigated the effect of pollutant exposure on three measures of adverse outcome: death in ICU within 30 days; acute renal failure on admission to ICU (creatinine $>133 \mu \mathrm{mol} / \mathrm{L}$ and 24 -hour urine output $<410 \mathrm{ml}$ ); and invasive ventilation occurring within the first 24 hours of ICU admission.

Further prespecified subgroup analyses were also performed: age divided into two groups $(<65$, $\geq 65$ ); admission APACHE III score (0-49, 50-99, $\geq 100)$, ICU length of stay (<7 days, 7-14 days, >14 days) and season of admission. Missing clinical data were not used in analyses. Length of stay and APACHE III score were set to missing for palliative or organ donation admissions, and length of stay was additionally set to missing if the patient died in ICU. For 30-day ICU mortality only age and season were considered. Conditional logistic regression models were run with and without the inclusion of a potential effect modifier and any improvement in fit tested for using a likelihood ratio test.

\section{Sensitivity analyses}

Sensitivity to residual seasonality was investigated by re-running analyses with the inclusion of a simple sine cosine annual cycle. We investigated whether any relationship between pollutant exposure and the log odds of ICU admission might be non-linear by modelling pollutant means (i.e. 
the average concentration over lag days 0-2) using 3 knot natural cubic spline. Lastly, we repeated analyses excluding inter-hospital transfers.

\section{$\underline{\text { Results }}$}

Pollutant data were obtained from 62 monitoring stations (Figure 1). Of the study period, pollution data were available for $75 \%$ of days for $\mathrm{NO}_{2}, 72 \%$ for $\mathrm{PM}_{10}$ and $40 \%$ for $\mathrm{PM}_{2.5}$. Seasonal trends in daily mean air quality for $\mathrm{PM}_{10}$ and $\mathrm{PM}_{2.5}$, categorised according to Australian National Environment Protection Council Ambient Air Quality Measure (AAQ NEPM) index [34] are shown in Figure 2.

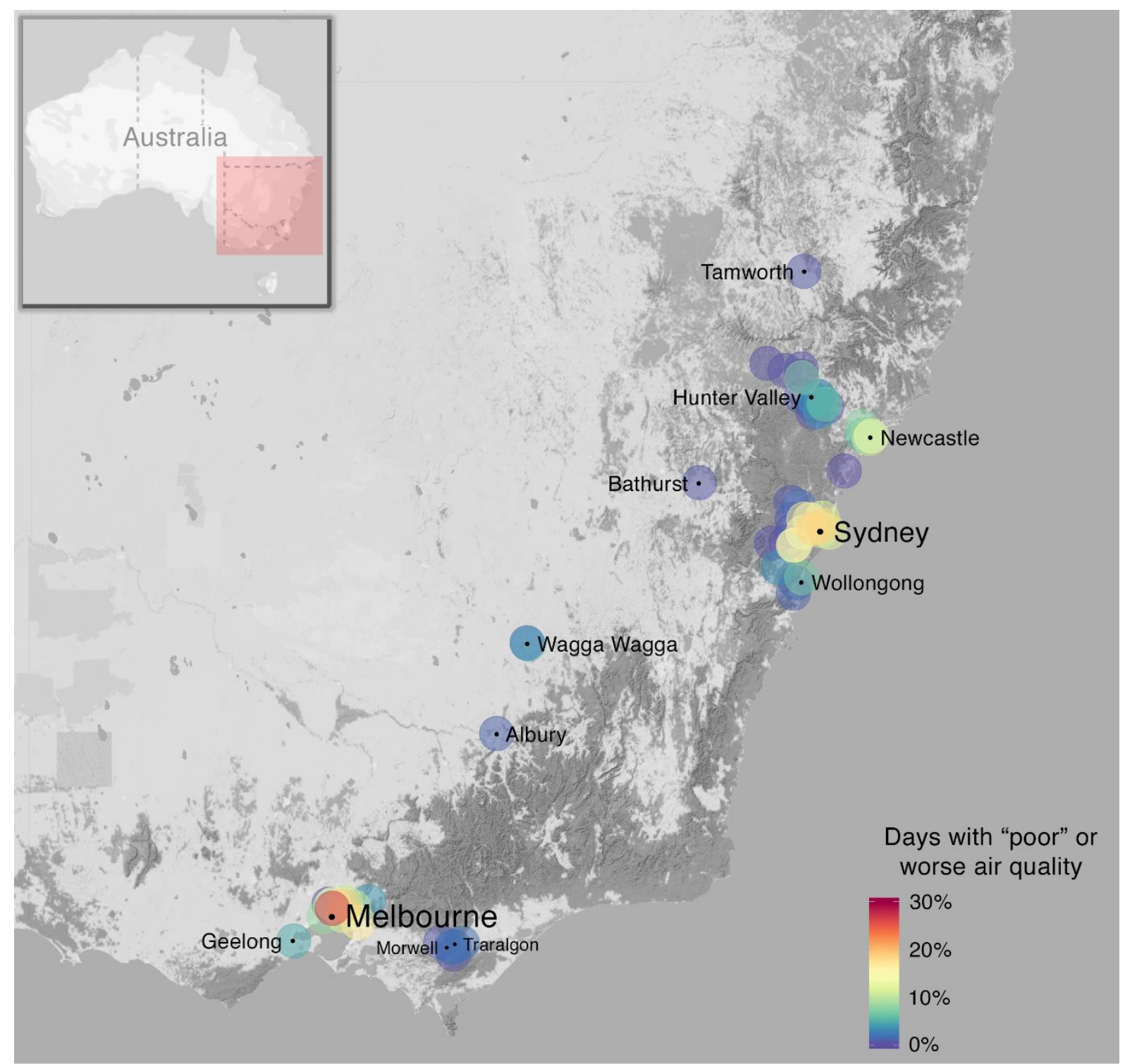

Figure 1. Location of the included 62 pollution monitoring stations and associated air quality over the duration of the study. Each point represents the location of a single station. The fill colour represents the proportion of days with a 24 hour mean level of $\mathrm{PM}_{10}, \mathrm{PM}_{2.5}$ or $\mathrm{NO}_{2}$ classifed as "poor" or "very poor" according to the AAQ NEPM index[34] 

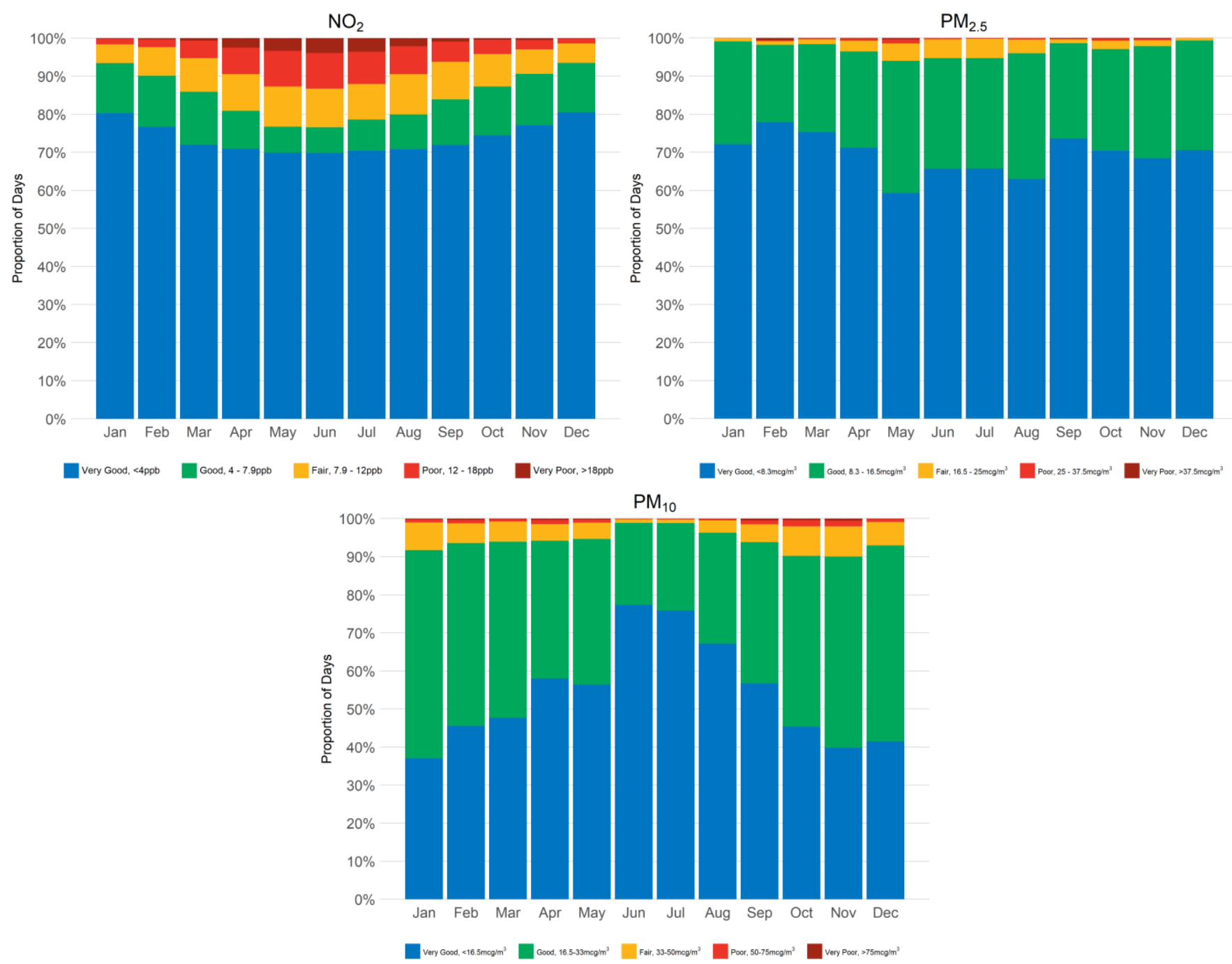

Figure 2. Seasonal trends observed in pollutant levels. The proportion of days per month classified by AAQ NEPM index at all stations, aggregated across the study duration. 
46,965 episodes in 87 separate ICUs satisfied inclusion criteria for the study. These patients were residents of 419 different postcodes. Data from 45 pollutant monitoring stations were used. The medians of daily mean pollutant concentrations were: $8 \mathrm{ppb}$ (inter-quartile range (IQR) 5 to 12) for $\mathrm{NO}_{2}, 6.2 \mu \mathrm{g} / \mathrm{m}^{3}$ (IQR: 4.3 to 8.8) for $\mathrm{PM}_{2.5}$ and $15.8 \mu \mathrm{g} / \mathrm{m}^{3}$ (IQR: 11.7 to 21.1) for $\mathrm{PM}_{10}$. Average within postcode Pearson correlation coefficients $(\bar{\rho})$ suggested that while daily mean concentrations of $\mathrm{PM}_{10}$ and $\mathrm{PM}_{2.5}$ were strongly positively correlated $(\bar{\rho}=0.694, \mathrm{~N}=291)$, correlations of $\mathrm{PM}_{10}$ and $\mathrm{PM}_{2.5}$ with $\mathrm{NO}_{2}$ concentrations, though still positive, were weaker $(\bar{\rho}=0.111, \mathrm{~N}=404$ and $\bar{\rho}=0.349, \mathrm{~N}=291$, respectively) (S3). Complete data with at least one control day was available for 36,510 ICU episodes for $\mathrm{NO}_{2}, 39,039$ for $\mathrm{PM}_{10}$ and 18,357 for $\mathrm{PM}_{2.5}$ (S4). In total, 40,775 individual ICU episodes were used in the analyses.

For each analysis we only included episodes with complete data on the pollutant of interest and all covariates (i.e. the climate variables, influenza like illness activity, and public holidays) on the admission day and at least one control day.

\section{$\underline{\text { Patient characteristics }}$}

Patient characteristics from all episodes used in analyses are summarised in Table 1.

\begin{tabular}{|l|c|}
\hline \multicolumn{1}{|c|}{ Characteristic } & $\mathrm{n}(\%)$ or Median (IQR) \\
\hline Total ICU Episodes & 40,775 \\
\hline \multicolumn{1}{|c|}{ Respiratory } & $16,863(41.4 \%)$ \\
\hline Cardiovascular & $11,636(28.5 \%)$ \\
\hline Sepsis & $10,725(26.3 \%)$ \\
\hline Stroke & $1,551(3.8 \%)$ \\
\hline Mortality in ICU & $5,661(13.9 \%)$ \\
\hline 30-day ICU mortality & $5,608(13.8 \%)$ \\
\hline Mortality in hospital & $8,093(19.9 \%)$ \\
\hline Age (years) & 67 (54 to 78) \\
\hline Male gender & $22,812(56 \%)$ \\
\hline ICU length of stay (days) & 3 (1 to 5) \\
\hline Acute renal failure in first 24 hours ICU & 4,127 (10.1\%) \\
\hline Invasive ventilation in first 24 hours ICU & 13,907 (34.2\%) \\
\hline Admission APACHE III score & 62 (45 to 84) \\
\hline
\end{tabular}

Table 1. Patient characteristics

\section{Main findings}

We found $\mathrm{PM}_{2.5}$ was significantly associated with increased 30-day ICU mortality (RR $1.18,95 \% \mathrm{Cl}$ $1.02-1.37$, per $10 \mu \mathrm{g} / \mathrm{m}^{3}$ ) after adjustment for covariates (Table 2). This association was strongest with $\mathrm{PM}_{2.5}$ concentrations on the day of admission (S5). No significant association was found between mortality and $\mathrm{PM}_{10}$ or $\mathrm{NO}_{2}$.

We found no evidence of an association between short-term exposure to $\mathrm{NO}_{2}, \mathrm{PM}_{2.5}$ or $\mathrm{PM}_{10}$ and ICU admissions (all cause or by disease subgroup), invasive ventilation or acute renal failure (Table 2). 


\begin{tabular}{|c|c|c|c|c|c|c|c|c|c|}
\hline & \multicolumn{3}{|c|}{$\mathrm{NO}_{2}$} & \multicolumn{3}{|c|}{$\mathrm{PM}_{2.5}$} & \multicolumn{3}{|c|}{$\mathrm{PM}_{10}$} \\
\hline & $\begin{array}{l}\text { No. } \\
\text { cases }\end{array}$ & $\begin{array}{c}\text { Unadjusted } \\
\mathrm{RR}^{\S}(95 \% \mathrm{Cl}) \text { per } \\
10 \mathrm{ppb}\end{array}$ & $\begin{array}{c}\text { Adjusted } \\
\mathrm{RR}^{\text {sๆ }}(95 \% \mathrm{Cl}) \\
\text { per 10ppb }\end{array}$ & $\begin{array}{l}\text { No. } \\
\text { cases }\end{array}$ & $\begin{array}{c}\text { Unadjusted } \\
\mathrm{RR}^{\S}(95 \% \mathrm{Cl}) \\
\text { per } 10 \mu \mathrm{g} / \mathrm{m}^{3}\end{array}$ & $\begin{array}{c}\text { Adjusted } \\
\operatorname{RR}^{\delta \uparrow}(95 \% \mathrm{Cl}) \\
\text { per } 10 \mu \mathrm{g} / \mathrm{m}^{3}\end{array}$ & $\begin{array}{l}\text { No. } \\
\text { cases }\end{array}$ & $\begin{array}{l}\text { Unadjusted } \\
\mathrm{RR}^{\S}(95 \% \mathrm{Cl}) \\
\text { per } 10 \mu \mathrm{g} / \mathrm{m}^{3}\end{array}$ & $\begin{array}{c}\text { Adjusted } \\
\operatorname{RR}^{\delta \uparrow}(95 \% \mathrm{Cl}) \\
\text { per } 10 \mu \mathrm{g} / \mathrm{m}^{3}\end{array}$ \\
\hline \multirow[t]{2}{*}{ ICU Admissions (total) } & 36,510 & $\begin{array}{c}1.015 \\
(0.970,1.062) \\
\end{array}$ & $\begin{array}{c}0.998 \\
(0.950,1.047) \\
\end{array}$ & 18,357 & $\begin{array}{c}1.020 \\
(0.976,1.066) \\
\end{array}$ & $\begin{array}{c}1.017 \\
(0.970,1.065) \\
\end{array}$ & 39,039 & $\begin{array}{c}1.002 \\
(0.994,1.011) \\
\end{array}$ & $\begin{array}{c}1.001 \\
(0.992,1.009) \\
\end{array}$ \\
\hline & 15,054 & $\begin{array}{c}0.977 \\
(0.910,1.048) \\
\end{array}$ & $\begin{array}{c}0.975 \\
(0.902,1.053) \\
\end{array}$ & 7,716 & $\begin{array}{c}1.030 \\
(0.965,1.099) \\
\end{array}$ & $\begin{array}{c}1.027 \\
(0.959,1.099) \\
\end{array}$ & 16,114 & $\begin{array}{c}1.004 \\
(0.994,1.015)\end{array}$ & $\begin{array}{c}1.003 \\
(0.992,1.014)\end{array}$ \\
\hline Cardiovascular & 10,466 & $\begin{array}{c}1.063 \\
(0.978,1.154)\end{array}$ & $\begin{array}{c}1.022 \\
(0.934,1.118)\end{array}$ & 4,870 & $\begin{array}{c}1.048 \\
(0.956,1.148)\end{array}$ & $\begin{array}{c}1.051 \\
(0.954,1.157) \\
\end{array}$ & 11,162 & $\begin{array}{c}1.003 \\
(0.983,1.023) \\
\end{array}$ & $\begin{array}{c}0.999 \\
(0.979,1.020)\end{array}$ \\
\hline Stroke & 1,376 & $\begin{array}{c}1.123 \\
(0.886,1.422) \\
\end{array}$ & $\begin{array}{c}1.176 \\
(0.910,1.519) \\
\end{array}$ & 777 & $\begin{array}{c}1.183 \\
(0.916,1.527) \\
\end{array}$ & $\begin{array}{c}1.287 \\
(0.975,1.699) \\
\end{array}$ & 1,476 & $\begin{array}{c}1.004 \\
(0.902,1.118) \\
\end{array}$ & $\begin{array}{c}1.012 \\
(0.898,1.141) \\
\end{array}$ \\
\hline Sepsis & 9,614 & $\begin{array}{c}1.008 \\
(0.923,1.100) \\
\end{array}$ & $\begin{array}{c}0.984 \\
(0.895,1.081) \\
\end{array}$ & 4,994 & $\begin{array}{c}0.935 \\
(0.851,1.027) \\
\end{array}$ & $\begin{array}{c}0.910 \\
(0.822,1.008) \\
\end{array}$ & 10,287 & $\begin{array}{c}0.986 \\
(0.962,1.012) \\
\end{array}$ & $\begin{array}{c}0.982 \\
(0.954,1.011) \\
\end{array}$ \\
\hline 30-day ICU mortality & 4,843 & $\begin{array}{c}1.027 \\
(0.910,1.160) \\
\end{array}$ & $\begin{array}{c}1.003 \\
(0.879,1.145) \\
\end{array}$ & 2332 & $\begin{array}{c}1.198^{* *} \\
(1.046,1.371) \\
\end{array}$ & $\begin{array}{c}1.182^{*} \\
(1.023,1.366) \\
\end{array}$ & 5,178 & $\begin{array}{c}1.026 \\
(0.994,1.060) \\
\end{array}$ & $\begin{array}{c}1.027 \\
(0.991,1.063)\end{array}$ \\
\hline Acute renal failure $^{\dagger}$ & 3,681 & $\begin{array}{c}0.966 \\
(0.840,1.111) \\
\end{array}$ & $\begin{array}{c}0.912 \\
(0.786,1.059) \\
\end{array}$ & 1,798 & $\begin{array}{c}1.015 \\
(0.894,1.151) \\
\end{array}$ & $\begin{array}{c}1.008 \\
(0.883,1.151) \\
\end{array}$ & 3,917 & $\begin{array}{c}0.978 \\
(0.938,1.019) \\
\end{array}$ & $\begin{array}{c}0.979 \\
(0.937,1.022) \\
\end{array}$ \\
\hline $\begin{array}{c}\text { Invasive ventilation } \\
\text { within } 24 \text { hours of } \\
\text { admission }\end{array}$ & 12,445 & $\begin{array}{c}1.011 \\
(0.938,1.090)\end{array}$ & $\begin{array}{c}0.980 \\
(0.904,1.064)\end{array}$ & 6,057 & $\begin{array}{c}1.041 \\
(0.964,1.125)\end{array}$ & $\begin{array}{c}1.048 \\
(0.966,1.137)\end{array}$ & 13,262 & $\begin{array}{c}1.001 \\
(0.985,1.018)\end{array}$ & $\begin{array}{c}0.996 \\
(0.978,1.015)\end{array}$ \\
\hline Clospin & $p=0$. & 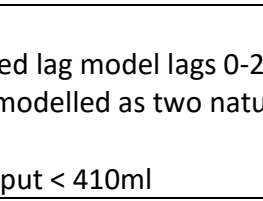 & . & & & & & & \\
\hline
\end{tabular}

Table 2. Relative risks of ICU admission categorised by admission diagnosis, and ICU admission with adverse outcome 


\begin{tabular}{|c|c|c|c|c|c|c|c|c|}
\hline & \multirow[b]{2}{*}{$\begin{array}{l}\text { Modifying } \\
\text { Factor }\end{array}$} & \multirow[b]{2}{*}{ Level } & \multicolumn{2}{|c|}{$\mathrm{NO}_{2}$} & \multicolumn{2}{|c|}{$\mathrm{PM}_{2.5}$} & \multicolumn{2}{|c|}{$\mathrm{PM}_{10}$} \\
\hline & & & $\begin{array}{c}\text { Adjusted } \\
\operatorname{RR}^{\delta \uparrow}(95 \% \mathrm{Cl}) \\
\text { per 10ppb }\end{array}$ & $\begin{array}{c}\text { Test for } \\
\text { modifying } \\
\text { effect } \\
P \text { value }\end{array}$ & $\begin{array}{c}\text { Adjusted } \\
\operatorname{RR}^{\delta \uparrow}(95 \% \mathrm{Cl}) \\
\text { per } 10 \mu \mathrm{g} / \mathrm{m}^{3}\end{array}$ & $\begin{array}{c}\text { Test for } \\
\text { modifying } \\
\text { effect } \\
P \text { value }\end{array}$ & $\begin{array}{c}\text { Adjusted } \\
\operatorname{RR}^{\S \uparrow}(95 \% \mathrm{Cl}) \\
\operatorname{per} 10 \mu \mathrm{g} / \mathrm{m}^{3}\end{array}$ & $\begin{array}{c}\text { Test for } \\
\text { modifying } \\
\text { effect } \\
\text { P value }\end{array}$ \\
\hline \multirow{8}{*}{$\begin{array}{c}\text { Total ICU } \\
\text { admissions }\end{array}$} & \multirow{3}{*}{$\begin{array}{l}\text { APACHE III } \\
\text { Score }\end{array}$} & $0-49$ & $\begin{array}{c}1.023 \\
(0.942,1.112)\end{array}$ & \multirow{3}{*}{0.655} & $\begin{array}{c}0.987 \\
(0.913,1.068)\end{array}$ & \multirow{3}{*}{0.832} & $\begin{array}{c}0.994 \\
(0.979,1.010)\end{array}$ & \multirow{3}{*}{0.217} \\
\hline & & $50-99$ & $\begin{array}{c}0.969 \\
(0.908,1.035)\end{array}$ & & $\begin{array}{c}1.034 \\
(0.970,1.101)\end{array}$ & & $\begin{array}{c}1.008 \\
(0.997,1.019)\end{array}$ & \\
\hline & & $\geq 100$ & $\begin{array}{c}1.050 \\
(0.938,1.175)\end{array}$ & & $\begin{array}{c}1.033 \\
(0.907,1.178)\end{array}$ & & $\begin{array}{c}0.971 \\
(0.938,1.006)\end{array}$ & \\
\hline & \multirow{3}{*}{$\begin{array}{l}\text { Length of stay } \\
\qquad \text { in } \mathrm{ICU}^{\ddagger}\end{array}$} & $<7$ days & $\begin{array}{c}1.017 \\
(0.961,1.077)\end{array}$ & \multirow{3}{*}{0.443} & $\begin{array}{c}0.992 \\
(0.938,1.049)\end{array}$ & \multirow{3}{*}{0.999} & $\begin{array}{c}0.996 \\
(0.985,1.007)\end{array}$ & \multirow{3}{*}{0.594} \\
\hline & & 7-14 days & $\begin{array}{c}0.920 \\
(0.802,1.054)\end{array}$ & & $\begin{array}{c}0.981 \\
(0.842,1.143)\end{array}$ & & $\begin{array}{c}0.999 \\
(0.967,1.031)\end{array}$ & \\
\hline & & $>14$ days & $\begin{array}{c}0.840 \\
(0.652,1.082)\end{array}$ & & $\begin{array}{c}0.931 \\
(0.703,1.234)\end{array}$ & & $\begin{array}{c}1.034 \\
(0.936,1.143)\end{array}$ & \\
\hline & \multirow{2}{*}{ Age } & $<65$ years & $\begin{array}{c}1.025 \\
(0.955,1.100)\end{array}$ & \multirow{2}{*}{0.759} & $\begin{array}{c}0.940 \\
(0.872,1.014)\end{array}$ & \multirow{2}{*}{0.001} & $\begin{array}{c}0.984 \\
(0.967,1.002)\end{array}$ & \multirow{2}{*}{0.005} \\
\hline & & $\geq 65$ years & $\begin{array}{c}0.977 \\
(0.918,1.040)\end{array}$ & & $\begin{array}{c}1.052 \\
(0.988,1.121)\end{array}$ & & $\begin{array}{c}1.006 \\
(0.994,1.018)\end{array}$ & \\
\hline \multirow{2}{*}{$\begin{array}{c}\text { 30-day ICU } \\
\text { mortality }\end{array}$} & \multirow{2}{*}{ Age } & $<65$ years & $\begin{array}{c}0.999 \\
(0.809,1.234)\end{array}$ & \multirow{2}{*}{0.846} & $\begin{array}{c}0.923 \\
(0.712,1.197)\end{array}$ & \multirow{2}{*}{0.023} & $\begin{array}{c}0.956 \\
(0.877,1.042)\end{array}$ & \multirow{2}{*}{0.005} \\
\hline & & $\geq 65$ years & $\begin{array}{c}1.007 \\
(0.858,1.182)\end{array}$ & & $\begin{array}{c}1.326 \\
(1.113,1.579)\end{array}$ & & $\begin{array}{c}1.070 \\
(1.007,1.138)\end{array}$ & \\
\hline \multicolumn{9}{|c|}{$\begin{array}{l}\text { § Relative risks based on an unconstrained distributed lag model lags 0-2 days } \\
\text { "Adjusted for temperature 0-2 days and 3-6 days prior (modelled as two natural cubic splines with } 3 \text { knots); humidity 0-2 days and 3-6 days prior (modelled as two natural cubic splines with } \\
3 \text { knots), flu activity score and public holidays. } \\
\text { ‡ Patients that died in ICU excluded from analyses. }\end{array}$} \\
\hline
\end{tabular}

Table 3. Subgroup analysis - relative risk of ICU admission and 30-day ICU mortality stratified by admission APACHE III score, ICU length of stay and age 


\section{Subgroup analyses}

The positive relationship between $\mathrm{PM}_{2.5}$ and 30-day ICU mortality was stronger in those aged 65 and over (RR 1.33, 95\% Cl $1.11-1.58$, per $\left.10 \mu \mathrm{g} / \mathrm{m}^{3}\right)$, whereas no association was found in under $65 \mathrm{~s}$. $\mathrm{PM}_{10}$ was also significantly associated with increased 30-day ICU mortality (RR 1.07, 95\% Cl 1.01 1.14 , per $10 \mu \mathrm{g} / \mathrm{m}^{3}$ ) in the over $65 \mathrm{~s}$ only.

There was no modifying effect of APACHE III score or length of stay on relationships between ICU admission and pollutants (Table 3). We found no modifying effect of season on admission or mortality (S6).

\section{$\underline{\text { Sensitivity analyses }}$}

Results in Table 2 were little changed by addition of a simple sine cosine annual cycle (S7), with no improvement in fit over a simple log-linear model for either $\mathrm{NO}_{2}(p=0.354), \mathrm{PM}_{2.5}(p=0.261)$ or $\mathrm{PM}_{10}$ $(p=0.381)$. Lastly, we repeated analyses shown in Table 2 excluding inter-hospital transfers (S8). The positive association between $\mathrm{PM}_{2.5}$ and 30 -day ICU mortality persisted (RR 1.19, 95\% Cl $1.01-1.41$, per $10 \mu \mathrm{g} / \mathrm{m}^{3}$ ), which was again driven by exposure on the day of admission. The previously observed negative association between risk of admission for sepsis with $\mathrm{PM}_{2.5}$ became even more negative, attaining statistical significance.

\section{Discussion}

This study is the first to investigate the relationship between air pollution, ICU admissions and outcome. Short-term exposure to pollution has been associated with mortality in general hospital populations, with additional high-risk groups identified [35]. Our study population has high mortality (approximately 10 to 15\% [36]) and widespread organ dysfunction, the pathophysiology of which overlaps that described in air pollution exposure, providing a possible mechanism for interaction. Our results support the hypothesis that the ICU population is affected by $\mathrm{PM}_{2.5}$ and warrants further study.

Our study design was informed by the strong association between pollution, cardio-respiratory disease and stroke. We also included sepsis based on its ubiquity in ICU, shared biological pathways and nascent associations with pollution [25,37]. As little is known about the effect of pollution on ICU population specifically, we studied only ICU admission and mortality and did not include postICU hospital mortality. Previous associations have been greatest over the first few days following exposure, with risk returning to baseline within a week [38,39]. Our study design reflects this and aims to mitigate the effect of hospital-acquired pathology by including only ICU admissions within 24 hours of hospital admission and death (in ICU) within 30 days.

We found a statistically significant increase in 30-day ICU mortality with higher exposure to $\mathrm{PM}_{2.5}$, a species particularly associated with harm when co-pollutant levels are controlled for [7]. However, there were no statistically significant associations between pollutants and the number of ICU admissions, both overall and within diagnostic groups. Point estimates for $\mathrm{PM}_{2.5}$ and ICU admission were positive except for sepsis (Table 2), suggesting it is possible that an association exists but we failed to detect it as statistically significant. Larger studies are required to investigate this relationship further. Another possible explanation for the increased mortality without increases in 
ICU admission is that $\mathrm{PM}_{2.5}$ may exert an effect on a vulnerable cohort of ICU patients, without increasing ICU admission for other individuals. Increases in cardiovascular mortality without excess hospital admissions have been observed elsewhere [40].

The effect estimate on ICU admission and dying in ICU within 30 days was an $18 \%(95 \% \mathrm{Cl} 2.3 \%$ $36.6 \%$ ) increase per $10 \mu \mathrm{g} / \mathrm{m}^{3}$ increase in $\mathrm{PM}_{2.5}$. This is considerably larger than observed in general population studies $[8,9]$ and may be due to the high-risk cohort we studied. This is supported by prespecified subgroup analysis of over 65s, in whom frailty is more common, and ICU prognosis is worse [41]. In this group, larger relative risk increases were found with exposure to both $\mathrm{PM}_{10}$ and $\mathrm{PM}_{2.5}$. This is consistent with other studies, which have shown the elderly to be particularly vulnerable to particulates $[8,16,17]$.

$\mathrm{PM}_{2.5}$ and $\mathrm{NO}_{2}$ levels were highest in the winter months (May - August), with $\mathrm{PM}_{10}$ levels highest in the spring and summer (September - February), a trend observed elsewhere $[42,43]$. Winter is associated with increases in ICU mortality, traditionally ascribed to influenza and cold weather (both of which were controlled for in this study). Our results suggest increased $\mathrm{PM}_{2.5}$ may also contribute. We conducted seasonal analyses to see if outcomes were affected by annual trends (e.g. summer bushfires) but did not detect significant differences.

We present relative risks per 10-unit increase in pollutant, as is standard in air pollution literature. Pollutant distributions were positively skewed, with low levels on most days ( $\mathrm{PM}_{2.5} 5 \%, 25 \%, 50 \%$, $75 \%$, 95\% percentiles: $2.3 \mu \mathrm{g} / \mathrm{m}^{3}, 4.3 \mu \mathrm{g} / \mathrm{m}^{3}, 6.2 \mu \mathrm{g} / \mathrm{m}^{3}, 8.8 \mu \mathrm{g} / \mathrm{m}^{3}, 14.4 \mu \mathrm{g} / \mathrm{m}^{3}$ ). Toxic levels for pollutants are unknown, and harm has been observed even with low levels [44]. The unprecedented 2019-20 bushfires in eastern Australia led to very high PM levels, presenting an opportunity to assess its impact on ICU patients.

\section{Weaknesses}

Short-term pollutant exposure is difficult to model, with significant variation over small areas. We used background monitoring station data, with a $10 \mathrm{~km}$ allowable distance from residential postcode, based on similar studies [45]. Individual exposure within this radius will vary with time spent outdoors, proximity to pollutant sources and accumulation or dispersion due to meteorological and topographical factors. Our study assumes subjects have been present at their residential postcode prior to admission. Additionally, postcode areas are often large and eccentrically shaped, making centroids imprecise for matching.

$21 \%$ of our ICU episodes were inter-hospital transfers. As the time of admission to the antecedent hospital is not collected by the APD, transfer arrival time was used, thus exposure modelling may be inaccurate in these cases. They were included as most represent transfers from small rural bases to regional ICUs occurring within hours of presentation, but this represents a weakness in the study. In sensitivity analyses, when these hospital transfers were excluded, the association between $\mathrm{PM}_{2.5}$ and 30-day mortality persisted, again driven by exposure on the day of admission.

APD clinical data is taken only from the first 24 hours of ICU admission, hence our study was not able to identify outcomes after this. Furthermore, only one admission diagnosis is provided, which does not reflect the complexity of most ICU admissions. 


\section{$\underline{\text { Conclusions }}$}

We observed an association between short-term $\mathrm{PM}_{2.5}$ exposure and mortality in a large and heterogeneous intensive care population. This adds to observational evidence that exposure to particulate matter is hazardous, and that critically ill patients may have increased sensitivity to outdoor air pollution. Further studies are required to determine if the number of ICU admissions increase with higher air pollution.

(Word count, excluding abstract, figures and references $=2,739$ ) 
1. Landrigan PJ, Fuller R, Acosta NJR et al. (2018) The Lancet Commission on pollution and health. Lancet 391 (10119):462-512. doi:10.1016/S0140-6736(17)32345-0

2. Brunekreef B, Holgate ST (2002) Air pollution and health. Lancet 360 (9341):1233-1242. doi:10.1016/S0140-6736(02)11274-8

3. Schwartz J, Dockery DW, Neas LM (1996) Is Daily Mortality Associated Specifically with Fine Particles? J Air Waste Manag Assoc 46 (10):927-939. doi:10.1080/10473289.1996.10467528

4. Latza U, Gerdes S, Baur X (2009) Effects of nitrogen dioxide on human health: systematic review of experimental and epidemiological studies conducted between 2002 and 2006. Int J Hyg Environ Health 212 (3):271-287. doi:10.1016/j.ijheh.2008.06.003

5. Bell ML, Dominici F, Samet JM (2005) A meta-analysis of time-series studies of ozone and mortality with comparison to the national morbidity, mortality, and air pollution study. Epidemiology 16 (4):436-445. doi:10.1097/01.ede.0000165817.40152.85

6. Katsouyanni K, Touloumi G, Spix C et al. (1997) Short-term effects of ambient sulphur dioxide and particulate matter on mortality in 12 European cities: results from time series data from the APHEA project. Air Pollution and Health: a European Approach. BMJ 314 (7095):1658-1663.

doi:10.1136/bmj.314.7095.1658

7. U.S. EPA. Integrated Science Assessment (ISA) for Particulate Matter (External Review Draft). (2018). https://cfpub.epa.gov/ncea/isa/recordisplay.cfm?deid=341593.

8. Zanobetti A, Schwartz J (2009) The effect of fine and coarse particulate air pollution on mortality: a national analysis. Environ Health Perspect 117 (6):898-903. doi:10.1289/ehp.0800108

9. Atkinson RW, Kang S, Anderson HR, Mills IC, Walton HA (2014) Epidemiological time series studies of PM2.5 and daily mortality and hospital admissions: a systematic review and meta-analysis. Thorax 69 (7):660-665. doi:10.1136/thoraxjnl-2013-204492

10. Feng S, Gao D, Liao F, Zhou F, Wang X (2016) The health effects of ambient PM2.5 and potential mechanisms. Ecotoxicol Environ Saf 128:67-74. doi:10.1016/j.ecoenv.2016.01.030

11. Fiordelisi A, Piscitelli P, Trimarco B, Coscioni E, laccarino G, Sorriento D (2017) The mechanisms of air pollution and particulate matter in cardiovascular diseases. Heart Fail Rev 22 (3):337-347. doi:10.1007/s10741-017-9606-7

12. U.S. EPA. Integrated Science Assessment (ISA) For Oxides Of Nitrogen - Health Criteria. (2016). https://cfpub.epa.gov/ncea/isa/recordisplay.cfm?deid=310879.

13. Liu C, Chen R, Sera F et al. (2019) Ambient Particulate Air Pollution and Daily Mortality in 652 Cities. N Engl J Med 381 (8):705-715. doi:10.1056/NEJMoa1817364

14. Mills IC, Atkinson RW, Kang S, Walton H, Anderson HR (2015) Quantitative systematic review of the associations between short-term exposure to nitrogen dioxide and mortality and hospital admissions. BMJ Open 5 (5):e006946. doi:10.1136/bmjopen-2014-006946

15. Shah AS, Lee KK, McAllister DA, Hunter A, Nair H, Whiteley W, Langrish JP, Newby DE, Mills NL (2015) Short term exposure to air pollution and stroke: systematic review and meta-analysis. BMJ 350:h1295. doi:10.1136/bmj.h1295

16. Di Q, Dai L, Wang Y, Zanobetti A, Choirat C, Schwartz JD, Dominici F (2017) Association of Shortterm Exposure to Air Pollution With Mortality in Older Adults. JAMA 318 (24):2446-2456. doi:10.1001/jama.2017.17923

17. Baccini M, Mattei A, Mealli F, Bertazzi PA, Carugno M (2017) Assessing the short term impact of air pollution on mortality: a matching approach. Environ Health 16 (1):7. doi:10.1186/s12940-0170215-7

18. Peters A, Dockery DW, Muller JE, Mittleman MA (2001) Increased particulate air pollution and the triggering of myocardial infarction. Circulation 103 (23):2810-2815.

doi:10.1161/01.cir.103.23.2810

19. Public Health England Committee on the Medical Effects of Air Pollutants (COMEAP): Air pollution and cardiovascular disease: mechanistic evidence. (2018).

https://www.gov.uk/government/publications/air-pollution-and-cardiovascular-diseasemechanistic-evidence. 
20. Rajagopalan S, Al-Kindi SG, Brook RD (2018) Air Pollution and Cardiovascular Disease: JACC Stateof-the-Art Review. J Am Coll Cardiol 72 (17):2054-2070. doi:10.1016/j.jacc.2018.07.099

21. De Weerdt A, Janssen BG, Cox B et al. (2020) Pre-admission air pollution exposure prolongs the duration of ventilation in intensive care patients. Intensive Care Med. doi:10.1007/s00134-02005999-3

22. Rhee J, Dominici F, Zanobetti A, Schwartz J, Wang Y, Di Q, Balmes J, Christiani DC (2019) Impact of Long-Term Exposures to Ambient PM2.5 and Ozone on ARDS Risk for Older Adults in the United States. Chest 156 (1):71-79. doi:10.1016/j.chest.2019.03.017

23. Ware LB, Zhao Z, Koyama T, May AK, Matthay MA, Lurmann FW, Balmes JR, Calfee CS (2016) Long-Term Ozone Exposure Increases the Risk of Developing the Acute Respiratory Distress Syndrome. Am J Respir Crit Care Med 193 (10):1143-1150. doi:10.1164/rccm.201507-14180C 24. Zhang Z, Hong Y, Liu N (2017) Association of ambient Particulate matter 2.5 with intensive care unit admission due to pneumonia: a distributed lag non-linear model. Scientific Reports 7 (1):8679. doi:10.1038/s41598-017-08984-x

25. Wei Y, Wang Y, Di Q, Choirat C, Wang Y, Koutrakis P, Zanobetti A, Dominici F, Schwartz JD (2019) Short term exposure to fine particulate matter and hospital admission risks and costs in the Medicare population: time stratified, case crossover study. BMJ 367:16258. doi:10.1136/bmj.16258 26. Stow PJ, Hart GK, Higlett T, George C, Herkes R, McWilliam D, Bellomo R, Committee ADM (2006) Development and implementation of a high-quality clinical database: the Australian and New Zealand Intensive Care Society Adult Patient Database. J Crit Care 21 (2):133-141. doi:10.1016/j.jcrc.2005.11.010

27. ANZICS CORE Data Access and Publication Policy. (2017) Australia and New Zealand Intensive Care Society. https://www.anzics.com.au/wp-content/uploads/2018/08/ANZICS-CORE-Data-Accessand-Publication-Policy.pdf. Accessed 20 November 2019

28. Air Pollution - Environment Protection Authority of Victoria https://www.epa.vic.gov.au/forcommunity/environmental-information/air-quality/air-pollution. Accessed 10 February 2020 29. Air- Office of Environment and Heritage of NSW. https://www.environment.nsw.gov.au/topics/air. Accessed 10 February 2020 30. Australian Public Holidays (Australian Government). https://www.australia.gov.au/aboutaustralia/special-dates-and-events/public-holidays. Accessed 10 February 2020

31. R: A language and environment for statistical computing. Version 3.3.3 ( 2017). R Foundation for Statistical Computing, Vienna, Austria.

32. Jaakkola JJ (2003) Case-crossover design in air pollution epidemiology. Eur Respir J Suppl 40:81s85s. doi:10.1183/09031936.03.00402703

33. Stata Statistical Software: Release 15. (2017). 15 edn. StataCorp LP. College Station, TX., 34. About the Air Quality Index. New South Wales Department of Planning, Industry and Environment. https://www.environment.nsw.gov.au/topics/air/understanding-air-quality-data/airquality-index. Accessed 3 January 2020

35. World Health Organisation Regional Office for Europe. Review of evidence on health aspects of air pollution - REVIHAAP Project: Technical Report. (2013).

https://www.ncbi.nlm.nih.gov/pubmed/27195369.

36. Wunsch H, Angus DC, Harrison DA, Linde-Zwirble WT, Rowan KM (2011) Comparison of medical admissions to intensive care units in the United States and United Kingdom. Am J Respir Crit Care Med 183 (12):1666-1673. doi:10.1164/rccm.201012-19610C

37. Rush B, Wiskar K, Fruhstorfer C, Celi LA, Walley KR (2018) The Impact of Chronic Ozone and Particulate Air Pollution on Mortality in Patients With Sepsis Across the United States. J Intensive Care Med:885066618804497. doi:10.1177/0885066618804497

38. Kim SY, Peel JL, Hannigan MP, Dutton SJ, Sheppard L, Clark ML, Vedal S (2012) The temporal lag structure of short-term associations of fine particulate matter chemical constituents and cardiovascular and respiratory hospitalizations. Environ Health Perspect 120 (8):1094-1099. doi:10.1289/ehp.1104721 
39. Braga AL, Zanobetti A, Schwartz J (2001) The lag structure between particulate air pollution and respiratory and cardiovascular deaths in 10 US cities. J Occup Environ Med 43 (11):927-933.

doi:10.1097/00043764-200111000-00001

40. Rosenlund M, Picciotto S, Forastiere F, Stafoggia M, Perucci CA (2008) Traffic-related air pollution in relation to incidence and prognosis of coronary heart disease. Epidemiology 19 (1):121-128. doi:10.1097/EDE.0b013e31815c1921

41. Duke GJ, Barker A, Knott Cl, Santamaria JD (2014) Outcomes of older people receiving intensive care in Victoria. Med J Aust 200 (6):323-326. doi:10.5694/mja13.10132

42. Hansen A, Bi P, Nitschke M, Pisaniello D, Ryan P, Sullivan T, Barnett AG (2012) Particulate air pollution and cardiorespiratory hospital admissions in a temperate Australian city: A case-crossover analysis. Sci Total Environ 416:48-52. doi:10.1016/j.scitotenv.2011.09.027

43. Jalaludin B, Mannes T, Morgan G, Lincoln D, Sheppeard V, Corbett S (2007) Impact of ambient air pollution on gestational age is modified by season in Sydney, Australia. Environ Health 6:16.

doi:10.1186/1476-069X-6-16

44. World Health Organisation Regional Office for Europe. Expert Consultation: Available evidence for the future update of the WHO Global Air Quality Guidelines. (2015).

http://www.euro.who.int/en/health-topics/environment-and-health/air-

quality/publications/2016/who-expert-consultation-available-evidence-for-the-future-update-ofthe-who-global-air-quality-guidelines-aqgs-2016.

45. Dominici F, Peng RD, Bell ML, Pham L, McDermott A, Zeger SL, Samet JM (2006) Fine particulate air pollution and hospital admission for cardiovascular and respiratory diseases. JAMA 295

(10):1127-1134. doi:10.1001/jama.295.10.1127

\section{Acknowledgements}

We acknowledge the Australian and New Zealand Intensive Care Society (ANZICS) Centre for Outcome and Resources Evaluation (CORE) Centre, the Environment Protection Authority of Victoria, the Office of Environment and Heritage of NSW and the Australian Bureau of Meteorology for providing the data used in the study. The authors and the ANZICS CORE management committee would like to thank clinicians, data collectors and researchers at all contributing sites (listed in S9).

\section{Electronic Supplementary Material}

\begin{tabular}{|l|l|l|}
\hline \multirow{2}{*}{} & 101.01 & Shock; cardiogenic \\
\cline { 2 - 3 } & 101.02 & Papillary muscle rupture \\
\cline { 2 - 3 } & 102.01 & $\begin{array}{l}\text { Cardiac arrest with or without respiratory arrest; for respiratory arrest see Respiratory } \\
\text { System }\end{array}$ \\
\cline { 2 - 3 } & 103.01 & Aneurysm, dissecting aortic \\
\cline { 2 - 3 } & 104.01 & Congestive heart failure \\
\cline { 2 - 3 } & 105.01 & Aneurysm/Pseudoaneurysm, other \\
\cline { 2 - 3 } & 105.02 & Thrombus, arterial \\
\cline { 2 - 3 } & 106.01 & Rhythm disturbance (primary, e.g. tachyarrhythmias, bradyarrhythymias) \\
\cline { 2 - 3 } & 106.02 & rhythm disturbance (conduction defect) \\
\cline { 2 - 3 } & 106.03 & Rhythm disturbance (atrial, supraventricular) \\
\cline { 2 - 3 } & 106.04 & Rhythm disturbance (ventricular) \\
\cline { 2 - 3 } & 107.01 & Infarction, acute myocardial (MI) \\
\cline { 2 - 3 } & 107.02 & Infarction, acute myocardial (MI), ANTERIOR \\
\cline { 2 - 4 } & 107.03 & Infarction, acute myocardial (MI), INFEROLATERAL \\
\cline { 2 - 4 } & 107.04 & Infarction, acute myocardial (MI), NON Q Wave \\
\cline { 2 - 3 } & 107.05 & Infarction, acute myocardial (MI), none of the above \\
\hline
\end{tabular}




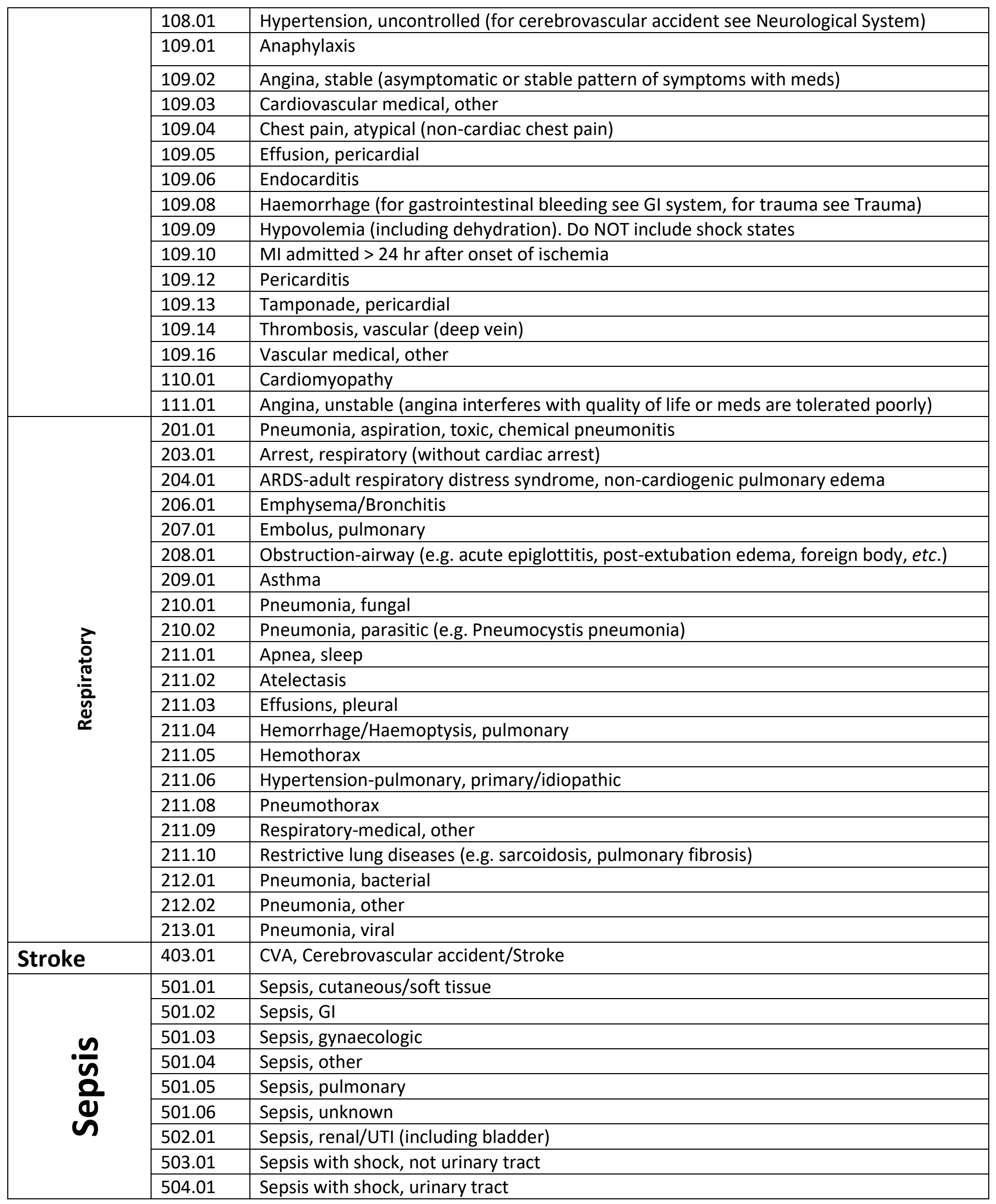




\section{APACHE III-J Diagnosis inclusions:}

\begin{tabular}{|c|c|c|}
\hline & 101 & Cardiogenic shock \\
\hline & 102 & Cardiac arrest \\
\hline $\mathbf{r}$ & 103 & Aneurysm, dissecting aortic \\
\hline & 104 & Congestive heart failure \\
\hline & 105 & Aneurysm/pseudoaneurysm, other \\
\hline & $\begin{array}{l}105 \\
106\end{array}$ & Rhythm disturbance \\
\hline & 107 & Acute myocardial infarction \\
\hline & 108 & Hypertension \\
\hline & 109 & Other cardiovascular disease \\
\hline & 110 & Cardiomyopathy \\
\hline & 111 & Unstable angina \\
\hline & 201 & Pneumonia, aspiration, toxic, chemical pneumonitis \\
\hline & 203 & Respiratory arrest \\
\hline & 204 & Pulmonary oedema - non-cardiac \\
\hline 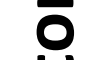 & 206 & Chronic obstructive pulmonary disease \\
\hline & 207 & Pulmonary embolism \\
\hline & 208 & Mechanical airway obstruction \\
\hline & 209 & Asthma \\
\hline & 210 & Parasitic pneumonia \\
\hline $\mathbf{\alpha}$ & 211 & Other respiratory diseases \\
\hline & 212 & Bacterial pneumonia \\
\hline & 213 & Viral pneumonia \\
\hline troke & 403 & Stroke \\
\hline $\boldsymbol{n}$ & 501 & Sepsis, other than urinary \\
\hline $\bar{n}$ & 502 & Sepsis of urinary tract origin \\
\hline & 503 & Sepsis with shock, other than urinary \\
\hline & 504 & Sepsis of urinary tract origin with shock \\
\hline
\end{tabular}

APACHE II Diagnosis inclusions:

\begin{tabular}{|c|c|c|}
\hline \multirow{6}{*}{ 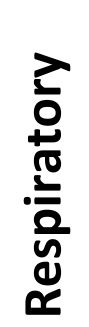 } & 101 & Asthma/Allergy \\
\hline & 102 & COPD \\
\hline & 103 & Pulmonary oedema (non-cardiogenic) \\
\hline & 105 & Pulmonary embolus \\
\hline & 106 & Respiratory infection \\
\hline & 108 & Post respiratory arrest (only) \\
\hline \multirow{7}{*}{ 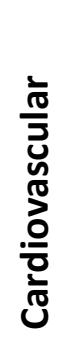 } & 303 & Respiratory undefined (non-op) \\
\hline & 109 & Hypertension \\
\hline & 110 & Congestive cardiac failure \\
\hline & 112 & Coronary artery disease \\
\hline & 114 & Post cardiac arrest (only) \\
\hline & 115 & Cardiogenic shock \\
\hline & 117 & Rhythm disturbance \\
\hline
\end{tabular}




$\begin{array}{lll} & 302 & \text { Cardiovascular undefined (non-op) } \\ \text { Sepsis } & 113 & \text { Sepsis (any aetiology) }\end{array}$

S1. APACHE diagnostic category inclusion criteria
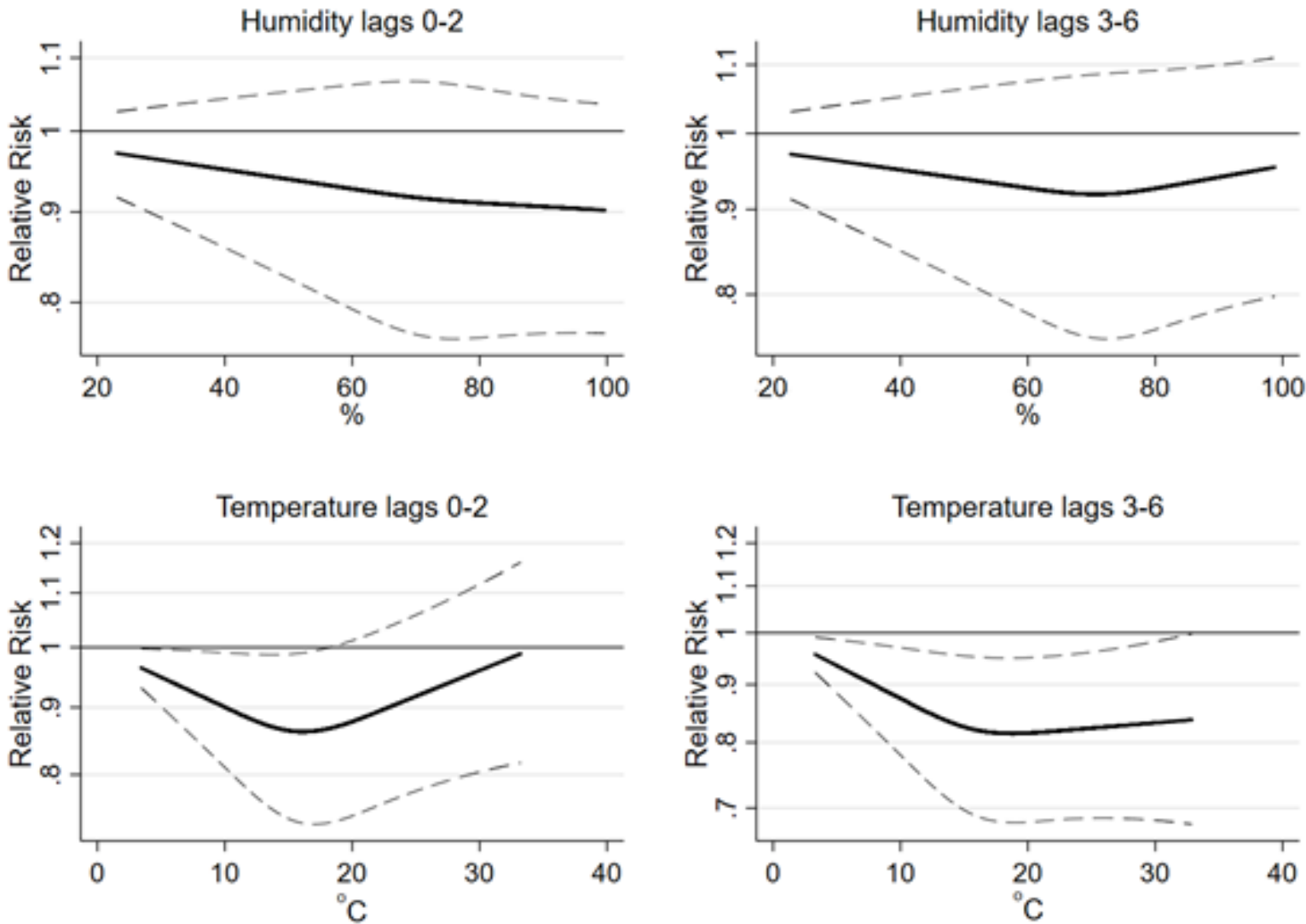

S2. The association between ICU admission and climate variables using 3 knot cubic splines. Dotted lines are $95 \%$ confidence intervals. Tests for improvement in fit over a simple log-linear model: top left $p=0.739$; top right $p=0.263$; bottom left $p=0.009$; bottom right $p=0.057$

\begin{tabular}{|c|c|c|c|c|c|}
\hline & $\begin{array}{c}\mathrm{NO}_{2} \\
\text { (ppb) }\end{array}$ & $\begin{array}{c}\mathrm{PM}_{2.5} \\
\left(\mu \mathrm{g} / \mathrm{m}^{3}\right)\end{array}$ & $\begin{array}{c}\mathrm{PM}_{10} \\
\left(\mu \mathrm{g} / \mathrm{m}^{3}\right)\end{array}$ & $\begin{array}{c}\text { Temperature } \\
(\circ \mathrm{C})\end{array}$ & $\begin{array}{c}\text { Relative Humidity } \\
(\%)\end{array}$ \\
\hline \multicolumn{6}{|c|}{ Daily mean pollutant concentrations: } \\
\hline No. of days $(n)$ & $1,198,528$ & 624,775 & $1,265,669$ & $1,360,010$ & $1,354,050$ \\
\hline Median & 8 & 6.2 & 15.8 & 16.25 & 71.70 \\
\hline IQR & 5 to 12 & 4.3 to 8.8 & 11.7 to 21.1 & 12.66 to 20.30 & 63.83 to 79.19 \\
\hline \multicolumn{6}{|l|}{ Within post-code means: } \\
\hline No. of postcodes (N) & 407 & 301 & 416 & 415 & 413 \\
\hline Mean & 8.84 & 7.25 & 17.6 & 16.56 & 70.84 \\
\hline Range & $1.79-12.94$ & $5.85-9.05$ & $12.8-22.7$ & $12.97-20.03$ & $62.69-82.42$ \\
\hline \multicolumn{6}{|c|}{ Average within-postcode correlation coefficients: } \\
\hline $\mathrm{PM}_{2.5}$ & $\begin{array}{c}0.349 \\
(\mathrm{~N}=291)\end{array}$ & & & & \\
\hline $\mathbf{P M}_{10}$ & $\begin{array}{c}0.111 \\
(\mathrm{~N}=404)\end{array}$ & $\begin{array}{c}0.694 \\
(\mathrm{~N}=291)\end{array}$ & & & \\
\hline Temperature & $\begin{array}{c}-0.355 \\
(\mathrm{~N}=403)\end{array}$ & $\begin{array}{c}0.068 \\
(\mathrm{~N}=300)\end{array}$ & $\begin{array}{c}0.241 \\
(\mathrm{~N}=411)\end{array}$ & & \\
\hline Humidity & 0.168 & 0.038 & -0.211 & -0.278 & \\
\hline
\end{tabular}




\begin{tabular}{|c|c|c|c|c|c|c|}
\hline & \multirow[t]{2}{*}{ Pollutant } & \multirow[t]{2}{*}{$\begin{array}{c}\text { No. of } \\
\text { episodes }\end{array}$} & \multicolumn{4}{|c|}{$\begin{array}{l}\text { Control days with } \\
\text { complete data }\end{array}$} \\
\hline & & & 1 & 2 & 3 & 4 \\
\hline \multirow{3}{*}{ Total ICU admissions } & $\mathrm{NO}_{2}$ & 36,510 & 890 & 5,369 & 19,714 & 10,537 \\
\hline & $\mathrm{PM}_{10}$ & 39,039 & 489 & 4,280 & 21,881 & 12,389 \\
\hline & $\mathrm{PM}_{2.5}$ & 18,357 & 620 & 2,995 & 9,821 & 4,921 \\
\hline \multirow{3}{*}{ Cardiovascular admissions } & $\mathrm{NO}_{2}$ & 10,466 & 231 & 1,490 & 5,662 & 3,083 \\
\hline & $\mathrm{PM}_{10}$ & 11,162 & 130 & 1,183 & 6,241 & 3,608 \\
\hline & $\mathrm{PM}_{2.5}$ & 4,870 & 146 & 782 & 2,616 & 1,326 \\
\hline \multirow{3}{*}{ Respiratory admissions } & $\mathrm{NO}_{2}$ & 15,054 & 364 & 2,189 & 8,141 & 4,360 \\
\hline & $\mathrm{PM}_{10}$ & 16,114 & 185 & 1,689 & 9,055 & 5,185 \\
\hline & $\mathrm{PM}_{2.5}$ & 7,716 & 262 & 1,230 & 4,114 & 2,110 \\
\hline \multirow{3}{*}{ Stroke admissions } & $\mathrm{NO}_{2}$ & 1,376 & 45 & 223 & 737 & 371 \\
\hline & $\mathrm{PM}_{10}$ & 1,476 & 31 & 178 & 835 & 432 \\
\hline & $\mathbf{P M}_{2.5}$ & 777 & 26 & 113 & 456 & 182 \\
\hline \multirow{3}{*}{ Sepsis admissions } & $\mathrm{NO}_{2}$ & 9,614 & 250 & 1,467 & 5,174 & 2,723 \\
\hline & $\mathrm{PM}_{10}$ & 10,287 & 143 & 1,230 & 5,750 & 3,164 \\
\hline & $\mathrm{PM}_{2.5}$ & 4,994 & 186 & 870 & 2,635 & 1,303 \\
\hline
\end{tabular}

S4. Number of episodes available for each pollutant and admission diagnosis category

(a)

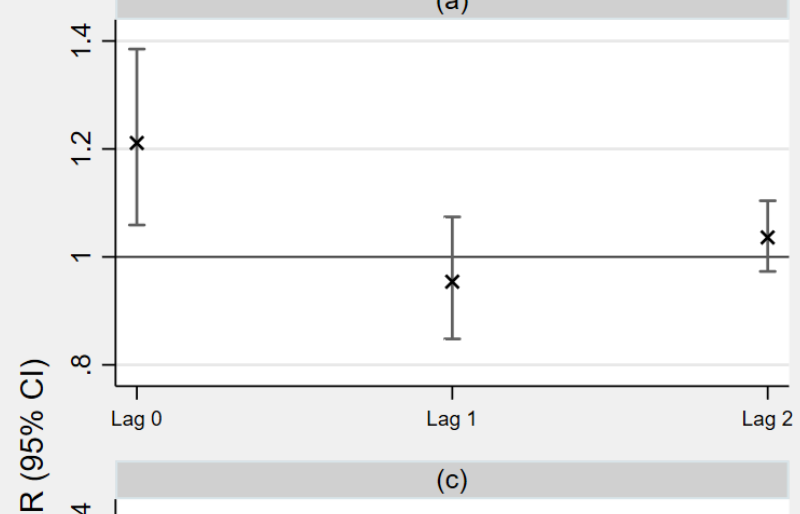

$\stackrel{x}{x}$

$\stackrel{+}{-}$
$\stackrel{-}{~}$

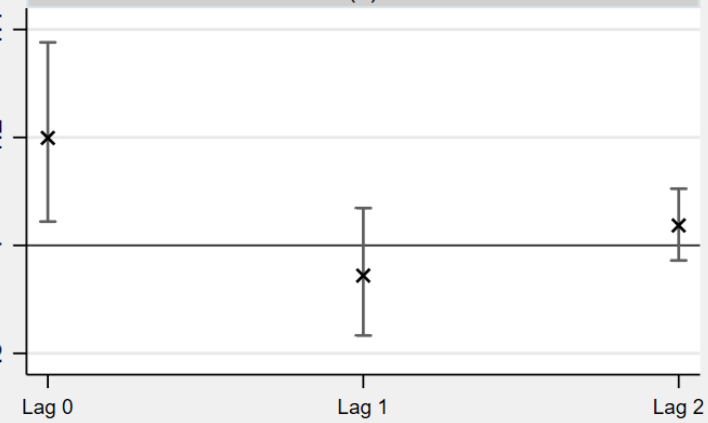

(b)

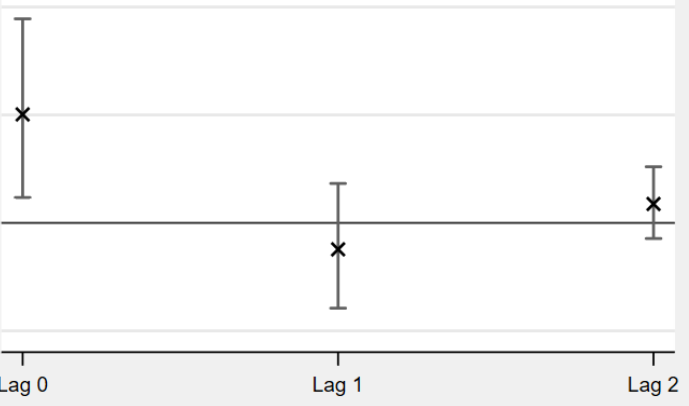

Lag 2

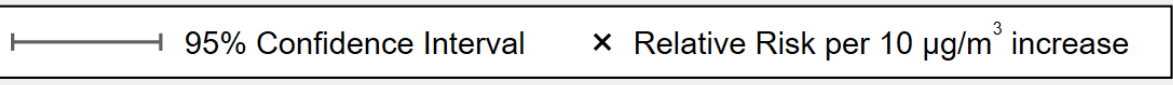

S5. The association between 30-day ICU mortality and exposure to $\mathrm{PM}_{2.5}$ on the day of hospital admission (lag 0), one day prior (lag 1) and two days prior (lag 2). (a) Unadjusted; (b) adjusted for temperature 0-2 days and 3-6 days prior (modelled 
as two natural cubic splines with 3 knots); humidity 0-2 days and 3-6 days prior (modelled as two natural cubic splines with 3 knots), flu activity score and public holidays; (c) as in (b) with additional adjustment for sine cosine annual cycle. 


\begin{tabular}{|c|c|c|c|c|c|c|c|}
\hline & \multirow[b]{2}{*}{ Season } & \multicolumn{2}{|c|}{$\mathrm{NO}_{2}$} & \multicolumn{2}{|c|}{$\mathrm{PM}_{2.5}$} & \multicolumn{2}{|c|}{$\mathrm{PM}_{10}$} \\
\hline & & $\begin{array}{c}\text { Adjusted } \\
\mathrm{RR}^{\delta \uparrow}(95 \% \mathrm{Cl}) \\
\text { per } 10 \mathrm{ppb}\end{array}$ & $\begin{array}{c}\text { Test for } \\
\text { modifying } \\
\text { effect } \\
P \text { value }\end{array}$ & $\begin{array}{c}\text { Adjusted } \\
\operatorname{RR}^{\delta q}(95 \% \mathrm{Cl}) \\
\text { per } 10 \mu \mathrm{g} / \mathrm{m}^{3}\end{array}$ & $\begin{array}{c}\text { Test for } \\
\text { modifying } \\
\text { effect } \\
P \text { value }\end{array}$ & $\begin{array}{c}\text { Adjusted } \\
\operatorname{RR}^{\delta q}(95 \% \mathrm{Cl}) \\
\text { per } 10 \mu \mathrm{g} / \mathrm{m}^{3}\end{array}$ & $\begin{array}{c}\text { Test for } \\
\text { modifying } \\
\text { effect } \\
\text { P value }\end{array}$ \\
\hline \multirow{4}{*}{$\begin{array}{c}\text { All ICU } \\
\text { admissions }\end{array}$} & Summer & $\begin{array}{c}1.016 \\
(0.905,1.140)\end{array}$ & \multirow{4}{*}{0.668} & $\begin{array}{c}0.975 \\
(0.845,1.125)\end{array}$ & \multirow{4}{*}{0.687} & $\begin{array}{c}0.993 \\
(0.953,1.036)\end{array}$ & \multirow{4}{*}{0.104} \\
\hline & Autumn & $\begin{array}{c}0.957 \\
(0.868,1.054)\end{array}$ & & $\begin{array}{c}0.976 \\
(0.882,1.080)\end{array}$ & & $\begin{array}{c}0.980 \\
(0.942,1.019)\end{array}$ & \\
\hline & Winter & $\begin{array}{c}0.992 \\
(0.920,1.070) \\
\end{array}$ & & $\begin{array}{c}1.022 \\
(0.923,1.130)\end{array}$ & & $\begin{array}{c}1.025 \\
(0.975,1.077) \\
\end{array}$ & \\
\hline & Spring & $\begin{array}{c}1.042 \\
(0.940,1.154) \\
\end{array}$ & & $\begin{array}{c}1.034 \\
(0.969,1.104)\end{array}$ & & $\begin{array}{c}1.000 \\
(0.991,1.010)\end{array}$ & \\
\hline \multirow{4}{*}{$\begin{array}{c}\text { 30-day ICU } \\
\text { mortality }\end{array}$} & Summer & $\begin{array}{c}0.935 \\
(0.681,1.285) \\
\end{array}$ & \multirow{4}{*}{0.924} & $\begin{array}{c}1.261 \\
(0.840,1.892)\end{array}$ & \multirow{4}{*}{0.372} & $\begin{array}{c}1.026 \\
(0.918,1.148)\end{array}$ & \multirow{4}{*}{0.945} \\
\hline & Autumn & $\begin{array}{c}0.913 \\
(0.706,1.180)\end{array}$ & & $\begin{array}{c}1.262 \\
(0.967,1.648)\end{array}$ & & $\begin{array}{c}1.019 \\
(0.918,1.131) \\
\end{array}$ & \\
\hline & Winter & $\begin{array}{c}1.000 \\
(0.816,1.226)\end{array}$ & & $\begin{array}{c}1.138 \\
(0.852,1.521)\end{array}$ & & $\begin{array}{c}1.084 \\
(0.946,1.243)\end{array}$ & \\
\hline & Spring & $\begin{array}{c}1.200 \\
(0.905,1.589)\end{array}$ & & $\begin{array}{c}1.168 \\
(0.888,1.538)\end{array}$ & & $\begin{array}{c}1.025 \\
(0.985,1.067)\end{array}$ & \\
\hline \multicolumn{8}{|c|}{${ }^{8}$ Relative risks based on an unconstrained distributed lag model lags 0-2 days prior } \\
\hline
\end{tabular}




\begin{tabular}{|c|c|c|c|c|c|c|}
\hline & \multicolumn{2}{|r|}{$\mathrm{NO}_{2}$} & \multicolumn{2}{|r|}{$\mathrm{PM}_{2.5}$} & \multicolumn{2}{|r|}{$\mathrm{PM}_{10}$} \\
\hline & $\begin{array}{l}\text { No. } \\
\text { cases }\end{array}$ & $\begin{array}{c}\text { Adjusted } \\
\operatorname{RR}^{\S \uparrow}(95 \% \mathrm{Cl}) \text { per } 10 \mu \mathrm{g} / \mathrm{m}^{3}\end{array}$ & $\begin{array}{l}\text { No. } \\
\text { cases }\end{array}$ & $\begin{array}{c}\text { Adjusted } \\
\operatorname{RR}^{\S \uparrow}(95 \% \mathrm{Cl}) \text { per } 10 \mu \mathrm{g} / \mathrm{m}^{3}\end{array}$ & $\begin{array}{l}\text { No. } \\
\text { cases }\end{array}$ & 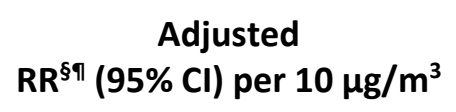 \\
\hline Admissions (total) & 36,510 & $\begin{array}{c}0.987 \\
(0.939,1.037)\end{array}$ & 18,357 & $\begin{array}{c}1.014 \\
(0.967,1.062)\end{array}$ & 39,039 & $\begin{array}{c}1.001 \\
(0.992,1.010)\end{array}$ \\
\hline Respiratory & 15,054 & $\begin{array}{c}0.961 \\
(0.889,1.039)\end{array}$ & 7,716 & $\begin{array}{c}1.026 \\
(0.958,1.098)\end{array}$ & 16,114 & $\begin{array}{c}1.003 \\
(0.992,1.015)\end{array}$ \\
\hline Cardiovascular & 10,466 & $\begin{array}{c}1.015 \\
(0.926,1.111)\end{array}$ & 4,870 & $\begin{array}{c}1.046 \\
(0.949,1.152)\end{array}$ & 11,162 & $\begin{array}{c}1.000 \\
(0.979,1.021)\end{array}$ \\
\hline Stroke & 1,376 & $\begin{array}{c}1.154 \\
(0.890,1.495)\end{array}$ & 777 & $\begin{array}{c}1.268 \\
(0.960,1.676)\end{array}$ & 1,476 & $\begin{array}{c}1.012 \\
(0.898,1.142)\end{array}$ \\
\hline Sepsis & 9,614 & $\begin{array}{c}0.975 \\
(0.886,1.073)\end{array}$ & 4,994 & $\begin{array}{c}0.903 \\
(0.815,1.001)\end{array}$ & 10,287 & $\begin{array}{c}0.982 \\
(0.954,1.012)\end{array}$ \\
\hline 30-day ICU mortality & 4,843 & $\begin{array}{c}0.985 \\
(0.861,1.126)\end{array}$ & 2,332 & $\begin{array}{c}1.172^{*} \\
(1.014,1.356)\end{array}$ & 5,178 & $\begin{array}{c}1.027 \\
(0.992,1.064)\end{array}$ \\
\hline Acute renal failure & 3,681 & $\begin{array}{c}0.900 \\
(0.773,1.047)\end{array}$ & 1,798 & $\begin{array}{c}1.002 \\
(0.875,1.147)\end{array}$ & 3,917 & $\begin{array}{c}0.979 \\
(0.937,1.022)\end{array}$ \\
\hline $\begin{array}{l}\text { Invasive ventilation } \\
\text { within } 24 \text { hours of } \\
\text { admission }\end{array}$ & 12,445 & $\begin{array}{c}0.969 \\
(0.892,1.052)\end{array}$ & 6,057 & $\begin{array}{c}1.043 \\
(0.961,1.132)\end{array}$ & 13,262 & $\begin{array}{c}0.997 \\
(0.978,1.016)\end{array}$ \\
\hline
\end{tabular}

S7. Sensitivity analysis: Investigating the association between ICU admission categorised by admission diagnosis, and admission with adverse outcome after additional adjustment for seasonality with a sine cosine annual cycle. 


\begin{tabular}{|c|c|c|c|c|c|c|}
\hline & \multicolumn{2}{|r|}{$\mathrm{NO}_{2}$} & \multicolumn{2}{|r|}{$\mathrm{PM}_{2.5}$} & \multicolumn{2}{|r|}{$\mathrm{PM}_{10}$} \\
\hline & $\begin{array}{l}\text { No. } \\
\text { cases }\end{array}$ & $\begin{array}{c}\text { Adjusted } \\
\mathrm{RR}^{\S \uparrow}(95 \% \mathrm{Cl}) \text { per } 10 \mathrm{ppb}\end{array}$ & $\begin{array}{l}\text { No. } \\
\text { cases }\end{array}$ & $\begin{array}{c}\text { Adjusted } \\
\operatorname{RR}^{\S \uparrow}(95 \% \mathrm{Cl}) \text { per } 10 \mathrm{\mu g} / \mathrm{m}^{3}\end{array}$ & $\begin{array}{l}\text { No. } \\
\text { cases }\end{array}$ & $\begin{array}{c}\text { Adjusted } \\
\operatorname{RR}^{\S \pi}(95 \% \mathrm{Cl}) \text { per } 10 \mu \mathrm{g} / \mathrm{m}^{3}\end{array}$ \\
\hline Admissions (total) & 28,840 & $\begin{array}{c}0.983 \\
(0.930,1.038) \\
\end{array}$ & 14,547 & $\begin{array}{c}0.969 \\
(0.913,1.028) \\
\end{array}$ & 30,968 & $\begin{array}{c}0.995 \\
(0.984,1.006)\end{array}$ \\
\hline Respiratory & 11,891 & $\begin{array}{c}0.953 \\
(0.874,1.040) \\
\end{array}$ & 6,170 & $\begin{array}{c}1.015 \\
(0.929,1.108) \\
\end{array}$ & 12,805 & $\begin{array}{c}1.001 \\
(0.987,1.015) \\
\end{array}$ \\
\hline Cardiovascular & 8,278 & $\begin{array}{c}1.020 \\
(0.922,1.128)\end{array}$ & 3,798 & $\begin{array}{c}0.964 \\
(0.855,1.087)\end{array}$ & 8,851 & $\begin{array}{c}0.988 \\
(0.962,1.015)\end{array}$ \\
\hline Stroke & 1,141 & $\begin{array}{c}1.141 \\
(0.862,1.509)\end{array}$ & 659 & $\begin{array}{c}1.337 \\
(0.978,1.828)\end{array}$ & 1,228 & $\begin{array}{c}1.023 \\
(0.895,1.169)\end{array}$ \\
\hline Sepsis & 7,530 & $\begin{array}{c}0.965 \\
(0.867,1.075)\end{array}$ & 3,920 & $\begin{array}{c}0.861^{*} \\
(0.762,0.973)\end{array}$ & 8,084 & $\begin{array}{c}0.972 \\
(0.937,1.009)\end{array}$ \\
\hline 30-day ICU mortality & 3,788 & $\begin{array}{c}0.980 \\
(0.844,1.138)\end{array}$ & 1,740 & $\begin{array}{c}1.192^{*} \\
(1.011,1.406)\end{array}$ & 4,070 & $\begin{array}{c}1.025 \\
(0.973,1.081)\end{array}$ \\
\hline Acute renal failure $^{\dagger}$ & 2,565 & $\begin{array}{c}0.925 \\
(0.774,1.105)\end{array}$ & 1,089 & $\begin{array}{c}0.951 \\
(0.782,1.156)\end{array}$ & 2,738 & $\begin{array}{c}0.942 \\
(0.879,1.009)\end{array}$ \\
\hline $\begin{array}{c}\text { Invasive ventilation within } \\
24 \text { hours of admission }\end{array}$ & 9,085 & $\begin{array}{c}0.986 \\
(0.897,1.085)\end{array}$ & 4,131 & $\begin{array}{c}0.957 \\
(0.859,1.066)\end{array}$ & 9,710 & $\begin{array}{c}0.984 \\
(0.959,1.011)\end{array}$ \\
\hline
\end{tabular}

\section{All $P$ values $>0.05$ except: ${ }^{*} p \leq 0.037$}

$\S$ Relative risks based on an unconstrained distributed lag model lags 0-2 days prior in the pollutant of interest.

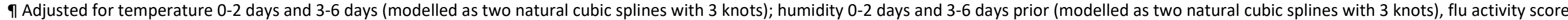

and public holidays.

+ Creatinine $>133 \mu \mathrm{mol} / \mathrm{L}$ and first 24 -hour urine output $<410 \mathrm{ml}$

S8. Sensitivity analysis: relative risks of ICU admission and ICU admission with adverse outcome with inter-hospital transfers removed 
Albury Wodonga Health ICU, Alfred Hospital ICU, Austin Hospital ICU, Ballarat Health Services ICU, Bankstown-Lidcombe Hospital ICU, Bathurst Base Hospital ICU, Bendigo Health Care Group ICU, Blacktown Hospital ICU, Box Hill Hospital ICU, Cabrini Hospital ICU, Calvary Mater Newcastle ICU, Campbelltown Hospital ICU, Central Gippsland Health Service (Sale) ICU, Coffs Harbour Health Campus ICU, Concord Hospital (Sydney) ICU, Dandenong Hospital ICU, Epworth Eastern Private Hospital ICU, Epworth Freemasons Hospital ICU, Epworth Hospital (Richmond) ICU, Figtree Private Hospital ICU, Footscray Hospital ICU, Frankston Hospital ICU, Gosford Hospital ICU, Gosford Private Hospital ICU, Goulburn Base Hospital ICU, Goulburn Valley Health ICU, Grafton Base Hospital ICU, Griffith Base Hospital ICU, Hornsby Ku-ring-gai Hospital ICU, John Fawkner Hospital ICU, John Hunter Hospital ICU, Kareena Private Hospital ICU, Knox Private Hospital ICU, Latrobe Regional Hospital ICU, Lismore Base Hospital ICU, Liverpool Hospital ICU, Macquarie University Private Hospital ICU, Manly Hospital \& Community Health ICU, Manning Rural Referral Hospital ICU, Maroondah Hospital ICU, Mater Private Hospital (Sydney) ICU, Melbourne Private Hospital ICU, Mildura Base Hospital ICU, Monash Medical Centre-Clayton Campus ICU, Mulgrave Private Hospital ICU, Nepean Hospital ICU, Newcastle Private Hospital ICU, North Shore Private Hospital ICU, Northeast Health Wangaratta ICU, Norwest Private Hospital ICU, Orange Base Hospital ICU, Peninsula Private Hospital ICU, Peter MacCallum Cancer Institute ICU, Port Macquarie Base Hospital ICU, Prince of Wales Hospital Sydney) ICU, Prince of Wales Private Hospital (Sydney) ICU, Royal Melbourne Hospital ICU, Royal Prince Alfred Hospital ICU, Shoalhaven Hospital ICU, South West Healthcare (Warrnambool) ICU, St George Hospital (Sydney) CICU, St George Hospital (Sydney) ICU, St George Hospital (Sydney) ICU2, St George Private Hospital (Sydney) ICU, St John of God Hospital (Bendigo) ICU, St John Of God Hospital (Geelong) ICU, St Vincent's Hospital (Melbourne) ICU, St Vincent's Hospital (Sydney) ICU, St Vincent's Private Hospital (Sydney) ICU, St Vincent's Private Hospital Fitzroy ICU, Sunshine Hospital ICU, Sutherland Hospital \& Community Health Services ICU, Sydney Adventist Hospital ICU, Sydney Southwest Private Hospital ICU, Tamworth Base Hospital ICU, The Northern Hospital ICU, Tweed Heads District Hospital ICU, University Hospital Geelong ICU, Wagga Wagga Base Hospital \& District Health ICU, Warringal Private Hospital ICU, Western District Health Service (Hamilton) ICU, Westmead Hospital ICU, Westmead Private Hospital ICU, Wimmera Health Care Group (Horsham) ICU, Wollongong Hospital ICU, Wollongong Private Hospital ICU, Wyong Hospital ICU

S9. Contributing sites

PM10 was measured using a Tapered Element Oscillating Microbalance (TEOM). PM2.5 was measured using Beta Attenuation Monitoring (BAM). 